\title{
PERSPECTIVES IN ETHOLOGY
}

Volume 7

Alternatives 


\section{CONTRIBUTORS}

Janis Antonovics

Department of Botany

Duke University

Durham, North Carolina 27706

\section{Anne Barrett Clark}

Kellogg Biological Station

Michigan State University

Hickory Corners, Michigan 49060

\section{John L. Craig}

Department of Zoology

University of Auckland

Auckland, New Zealand

\section{Timothy J. Ehlinger}

Kellogg Biological Station

Michigan State University

Hickory Corners, Michigan 49060

\section{Deborah M. Gordon}

Museum of Comparative Zoology and Society of Fellows

Harvard University

Cambridge, Massachusetts 02138

\section{Ian G. Jamieson}

Department of Zoology

University of Auckland

Auckland, New Zealand

\section{Andrew P. King}

Department of Psychology

Duke University

Durham, North Carolina 27706

\section{Robert W. Mitchell \\ Department of Psychology \\ Clark University \\ Worcester, Massachusetts 01610}

\author{
Nadav Nur \\ Department of Biological Science \\ University of Stirling \\ Stirling FK9 4LA, Scotland
}

\author{
J. G. Ollason \\ Culterty Field Station \\ University of Aberdeen \\ Newburgh, Ellon \\ Aberdeenshire AB4 OAA, Scotland
}

\section{H. Ronald Pulliam \\ Department of Zoology \\ University of Georgia \\ Athens, Georgia 30602}

\section{Nicholas S. Thompson}

Departments of Psychology and Biology

Clark University

Worcester, Massachusetts 01610

Marcy K. Uyenoyama

Department of Zoology

Duke University

Durham, North Carolina 27706

\section{Meredith J. West}

Department of Psychology

University of North Carolina

Chapel Hill, North Carolina 27514

A Continuation Order Plan is available for this series. A continuation order will bring delivery of each new volume immediately upon publication. Volumes are billed only upon actual shipment. For further information please contact the publisher. 


\title{
PERSPECTIVES IN ETHOLOGY
}

Volume 7

\section{Alternatives}

\author{
Edited by \\ P. P. G. Bateson \\ Sub-Department of Animal Behaviour \\ University of Cambridge \\ Cambridge, England

\section{and}

\section{Peter H. Klopfer} \\ Department of Zoology \\ Duke University \\ Durham, North Carolina
}


The Library of Congress has cataloged this title as follows:

Perspectives in ethology. - Vol. 1- - New York: Plenum Press, 1973v.: ill.; $24 \mathrm{~cm}$.

Irregular.

Includes bibliographies and indexes.

Editors: v. 1- P.P.G. Bateson and P. H. Klopfer.

ISSN 0738-4394 $=$ Perspectives in ethology.

1. Animal behavior-Collected works. I. Bateson, P. P. G. (Paul Patrick Gordon), 1938- . II. Klopfer, Peter H. [DNLM: W1 PE871AN]

QL750.P47

$591.5^{\prime} 1-\mathrm{dc} 19$

86-649219

Library of Congress

[8610]

AACR 2 MARC-S

ISBN-13: 978-1-4612-9015-5 e-ISBN-13: 978-1-4613-1815-6

DOI: $10.1007 /$ 978-1-4613-1815-6

(c) 1987 Plenum Press, New York

Softcover reprint of the hardcover 1st edition 1987

A Division of Plenum Publishing Corporation

233 Spring Street, New York, N.Y. 10013

All rights reserved

No part of this book may be reproduced, stored in a retrieval system, or transmitted in any form or by any means, electronic, mechanical, photocopying, microfilming, recording, or otherwise, without written permission from the Publisher 


\section{PREFACE}

This volume is subtitled "Alternatives" because we wanted to devote at least a part of it to the alternative ways in which members of the same species behave in a given situation. Not so very long ago the supposition among many ethologists was that if one animal behaved in a particular way, then all other members of the same age and sex would do the same. Any differences in the ethogram between individuals were to be attributed to "normal biological variation." Such thinking is less common nowadays after the discovery of dramatic differences between members of the same species which are of the same age and sex. Alternative modes of behavior, though now familiar, raise particularly interesting questions about current function, evolutionary history, and mechanism. Do the differences represent equally satisfactory solutions to a given problem? Are some of the solutions the best that those animals can do, given their body size and general condition? Is an alternative solution adopted because so many other individuals have taken the first? If so, do the frequencies reached at equilibrium depend on differential survival of genetically distinct types or do they result from decisions taken by individual animals? If the alternatives are induced during development, as are the castes of social insects, what is required for such triggering?

The questions about alternative ways of behaving are addressed in some of the chapters in this volume. However, other chapters have moved away from this theme and represent alternative modes of thinking about behavioral biology. In keeping with our intention, announced in the Preface to Volume 6 of Perspectives in Ethology, we have reverted to a more eclectic editorial policy. We have welcomed original essays that explored distinctive and even unpopular approaches to the subject. The 
mathematician Anatole Holt used to declare that the duty of scientists was to create distorting lenses so that the world could be viewed from many different perspectives. We think he was right and believe that our subject, like others, can only benefit from the airing of heterodox views.

Perhaps the most contentious issue discussed by different authors in this volume is the approach to the current function of behavior and the implication that when a job is well done by an animal it represents "good design." In Chapter 1 Clark and Ehlinger examine functional explanations for individual differences, arguing that nonadaptive explanations cannot be tested. They proceed to develop a framework in which the occurrence or nonoccurrence of differences can be related to the life history and ecology of the species. Nur examines alternative functional explanations for variation in the clutch size of birds in Chapter 2. He favors the view that these differences represent the outcome of year-toyear fluctuations in selection pressure. Jamieson and Craig also consider an aspect of parental behavior in birds in Chapter 3. In dealing with parent-helping behavior, they reject direct functional explanations and suggest that the feeding of nestlings in communal breeders is maintained by the same mechanism that results in parents feeding their own young.

The next two chapters are concerned explicitly with evolutionary issues. In Chapter 4 Pulliam reexamines the old problem of whether population density is regulated by the behavior of individuals. He argues that such cases exist and do not present such a problem for evolutionary explanations in terms of individual selection as has sometimes been supposed in the past; they may be interpreted in terms of the benefits derived by each of the active agents in the population. In Chapter 5 Uyenoyama and Antonovics examine another controversial issue, namely the extent to which inbreeding may have certain benefits. In the zoological literature it is commonly supposed that inbreeding should be avoided under all circumstances. Yet many plants self-pollinate and others (along with some animals) cope well when practicing biparental inbreeding. A history of being purged of deleterious recessive genes may greatly reduce or even eliminate the costs of inbreeding while simultaneously enhancing the relative costs of outbreeding.

Chapters 6 and 7 are primarily concerned with developmental issues. King and West draw on their own extensive studies of the social development of cowbirds and consider the various ways in which behavior can be inherited. After examining the dynamics of development they are led by their evidence to reject Ernst Mayr's famous dichotomizing of behavior as being driven by either "open" or "closed" programs. Many similarities between offspring and parent may depend on imitation, which is the topic discussed by Mitchell in Chapter 7. He considers the approaches to the 
subject by some great figures of the past and suggests that the differences between them can be reconciled within a scheme of nested levels. At the lowest level imitations are based on evolution and morphogenesis alone; at the next level they depend on perception and action. At the third level they depend on learning, at the fourth on self-awareness, and, finally, at the fifth on the awareness of another's awareness.

The last three chapters deal specifically with different approaches to the study of behavior. In Chapter 8 Gordon points out that, conventionally, group behavior has been inferred from the actions of individuals. Drawing on her own work on the group behavior of harvester ants, she suggests that it is both possible and desirable to measure the behavior of a group as an entity in its own right. In Chapter 9 Ollason adopts a line that will be unpopular among many behavioral ecologists since he attacks the optimal design approach, which has been so fashionable in the last few years. He argues that its application to animal behavior depends on circular reasoning. By contrast, Thompson makes a case for objective teleological approaches to function and "design," which he refers to as "teleonomic." However, he suggests that, in order to break the circularity in much current thinking, the evidence must be clearly distinguished from the evolutionary interpretations that are used to explain such evidence. We believe these last two chapters will perform a valuable service in sharpening thought about teleological approaches in the study of behavior.

The contributions to this volume deal with the alternative ways in which animals may behave and the alternative ways in which scientists seek to explain what they do. As for the future, we shall be happy to hear from those who have completed manuscripts and also those who have proposals for articles. Though we shall continue to develop particular themes through invited contributions, we believe that the strength of this series often lies in the chapters we had not anticipated.

\section{P. P. G. Bateson}

Sub-Department of Animal Behavior University of Cambridge

Madingley, Cambridge CB 3 8AA England
Peter H. Klopfer

Department of Zoology

Duke University

Durham, North Carolina 27706 


\section{CONTENTS}

Chapter 1

PATTERN AND ADAPTATION IN INDIVIDUAL BEHAVIORAL DIFFERENCES

\section{Anne Barrett Clark and Timothy J. Ehlinger}

I. Abstract .......................... 1

II. Introduction ......................... 2

III. Semantic Issues. . . . . . . . . . . . . . . . . . 5

IV. The Occurrence and Form of Individuality ......... 7

A. Social Behavior ................. 8

B. Foraging Behavior ................. 22

C. Advantages and Disadvantages of Being Different ... 29

V. Adaptation and the Process of Differentiation ........ 31

A. Introduction ................... 31

B. Stages and Shifting Characteristics .......... 35

C. Covert Differences and Threshold Effects ........ 36

VI. Acknowledgments........................ 39

VII. References............................ 39

Chapter 2

ALTERNATIVE REPRODUCTIVE TACTICS IN BIRDS: INDIVIDUAL VARIATION IN CLUTCH SIZE

Nadav Nur

I. Abstract $\ldots \ldots \ldots \ldots \ldots \ldots \ldots \ldots \ldots \ldots \ldots \ldots \ldots$ 


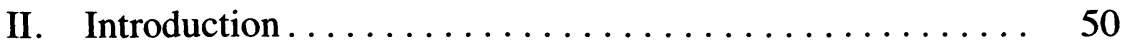

A. Individual Variation in Clutch Size .......... 51

B. Clutch Size: Proximal Influences . . . . . . . . . 53

III. Hypotheses to Account for Clutch Size Variation ...... 54

IV. Evaluation of the Evidence ................ 57

A. The Individual Optimization Hypothesis . . . . . . . 57

B. The Tradeoff Hypothesis ................ 61

C. The Fluctuating Selection Pressures Hypothesis . . . . . 64

V. Conclusions Regarding the Three Hypotheses ........ 67

VI. Discussion ........................ 70

A. Why Should Selection Pressures Fluctuate? ....... 70

B. Implications: Life in a Fluctuating Environment .... 72

VII. Acknowledgments.................... 75

VIII. References....................... 76

Chapter 3

CRITIQUE OF HELPING BEHAVIOR IN BIRDS: A DEPARTURE FROM FUNCTIONAL EXPLANATIONS

\section{Ian G. Jamieson and John L. Craig}

I. Abstract .......................... 79

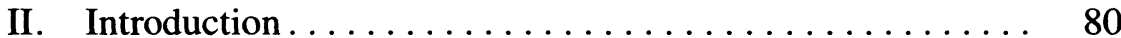

III. Criticisms and Alternatives ................ 81

A. How Is Helping Behavior Perceived? . . . . . . 81

B. Control of Provisioning Behavior .......... 82

C. In What Contexts Is Provisioning Behavior Observed? 83

D. Provisioning Behavior in Communal Breeders ...... 85

E. Development and Evolution of Communal Breeding .. 89

F. How Is Provisioning Behavior Maintained in Communal Breeders? ....................... 91

IV. Discussion ........................... 93

V. Acknowledgments....................... 95

VI. References........................ 96

Chapter 4

ON THE EVOLUTION OF DENSITY-REGULATING BEHAVIOR

\section{H. Ronald Pulliam}

I. Abstract ....................... 99

II. Introduction ......................... 100

A. The Controversy over Group Selection .......... 101 
B. Individual Selection and Individual Preferences . . . . . 103

III. The Haystack Model ... . . . . . . . . . . . . . . . . . . . 104

IV. Breeding Site Limitation .................. 105

V. Habitat Selection in the Nonbreeding Season ......... 108

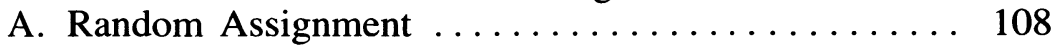

B. Ideal Avoidance ...................... 111

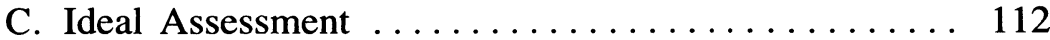

D. Ideal Dominance......................... 113

E. The Assessment Dominance Distribution (ADD) . . . . 114

VI. Population Dynamics ..................... 115

A. Density Dependence in Two Seasons ........... 115

B. Nest Site Selection and Geographic Range ........ 117

VII. Discussion of Model Assumptions ................ 119

VIII. Wynne Edwards Theory Reconsidered ............. 121

IX. Acknowledgment...................... 122

X. References...................... 122

Chapter 5

THE EVOLUTIONARY DYNAMICS OF MIXED MATING SYSTEMS: ON THE ADAPTIVE VALUE OF SELFING AND BIPARENTAL INBREEDING

Marcy K. Uyenoyama and Janis Antonovics

I. Abstract ........................ 125

II. Introduction . . . . . . . . . . . . . . . . 126

III. Determination of the Adaptive Value of Selfing . . . . . . 127

A. Response of Characters Correlated with Selection .... 127

B. Modification to Accommodate the Evolution of Transmission ... . . . . . . . . . . . . . . . . 128

C. Inbreeding Depression and Reproductive Mode of Origin As Determinants of Tradeoffs in Offspring Number . . . . . . . . . . . . . . . . . . . . 132

D. The Effect of Uniparental and Biparental Inbreeding on the Selective Advantage of Selfing .......... 133

IV. Three Regular Systems of Biparental Inbreeding . . . . . . . 134

A. Regular Systems of Inbreeding . . . . . . . . . 134

B. The Effect of Prior Inbreeding on the Condition Permitting the Increase of Selfing under Negligible Inbreeding Depression ................. 135

C. The Effect of Biparental Inbreeding on the Adaptive Value of Selfing in the Presence of Significant Inbreeding Depression 
D. A Summary of the Qualitative Effects of Biparental Inbreeding on the Evolution of Selfing . . . . . . . . 136

V. Discussion ......................... 137

A. Toward a Predictive Theory of Mating System Dynamics ......................... 137

B. Genetic Variation in Reproductive Mode ......... 138

C. The Resemblance between Parents and Their

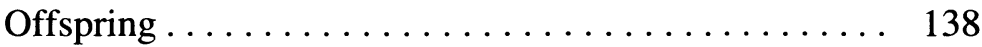

D. Empirical Estimates of Tradeoffs in Offspring Number . . . . . . . . . . . . . . . . . . . . . . . . 139

E. Long-Term and Short-Term Effects of Selfing on Progeny Variance .................... 141

F. The Effect of Selfing on Male Success .......... 141

G. Implications of Biparental Inbreeding for the Adaptive

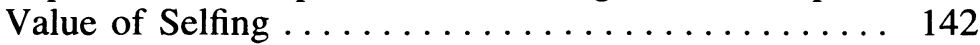

H. Consequences of Environmentally Imposed Shifts in the Breeding System .................. 142

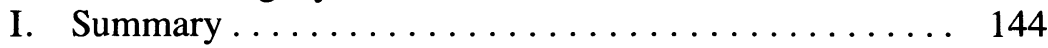

VI. Appendix A ....................... 146

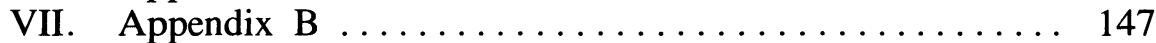

VIII. Appendix C . . . . . . . . . . . . . . . . . . 148

IX. Acknowledgments........................ 149

X. References.......................... 149

Chapter 6

THE EXPERIENCE OF EXPERIENCE: AN EXOGENETIC PROGRAM FOR SOCIAL COMPETENCE

\section{Andrew P. King and Meredith J. West}

I. Abstract ........................ 153

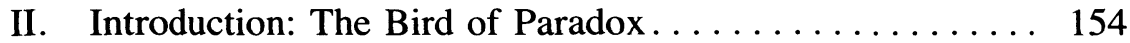

III. Methods of Inquiry: Functional Metrics of Communication ......................... 155

IV. Male Inheritance: An Embarassment of Riches? . . . . . . 159

V. Female Cowbirds: Like Mother, Like Daughter. . . . . . . 160

VI. Male Modifiability: Behind Closed Doors ........... 162

VII. The Female: A Connoisseur of Fine Song . . . . . . . . . 169

VIII. Population Comparisons: The Perspective from the Prairie ......................... 171 
IX. General Perspectives: Exogenetic Programs for Development ......................... 173

X. A Final Perspective: The Cowbird's Place in Nature's Gallery........................ 178

XI. Acknowledgments. . . . . . . . . . . . . . . . . . . . . 179

XII. References............................. 179

Chapter 7

A COMPARATIVE-DEVELOPMENTAL APPROACH TO UNDERSTANDING IMITATION

Robert W. Mitchell

I. Abstract ...................... 183

II. Introduction . . . . . . . . . . . . . . . . . . . . 184

III. Baldwin, Morgan, Guillaume, and Piaget on Imitation. . 186

A. James Mark Baldwin .................... 186

B. Conwy Lloyd Morgan ................... 187

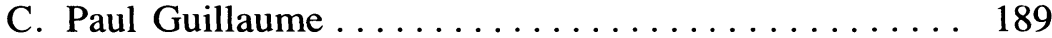

D. Jean Piaget $\ldots \ldots \ldots \ldots \ldots \ldots \ldots \ldots \ldots \ldots \ldots 19 \ldots \ldots \ldots \ldots$

E. Similarities and Differences . . . . . . . . . . . . 193

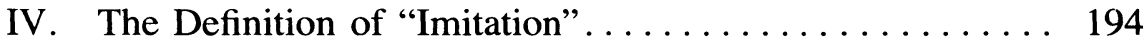

V. The Levels of Imitation . . . . . . . . . . . . . . . . . . . 200

A. First-Level Imitation.................. 202

B. Second-Level Imitation . . . . . . . . . . . . . . . 203

C. Third-Level Imitation . . . . . . . . . . . . . . . . . 205

D. Fourth-Level Imitation . . . . . . . . . . . . . . . 206

E. Fifth-Level Imitation. . . . . . . . . . . . . . . . . . . . 209

F. Clarifications ....................... 211

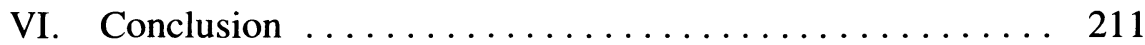

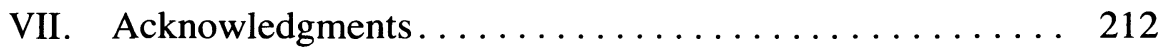

VIII. References........................ 212

Chapter 8

THE DYNAMICS OF GROUP BEHAVIOR

Deborah M. Gordon

I. Abstract ......................... 217

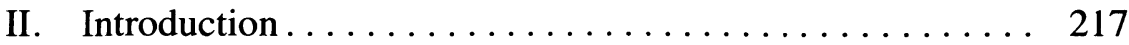

A. What Is Group Behavior? ............... 217

B. Why Study Group Behavior?............... 219 
III. Investigating Group Behavior: An Example of the Approach....................... 221

A. The Daily Round As a Unit of Group Behavior ..... 221

B. The Individual in Group Context........... 223

C. Dynamics of Group Behavior .............. 224

IV. Extending the Approach .................. 227

V. Acknowledgments........................ 230

VI. References........................... 230

Chapter 9

ARTIFICIAL DESIGN IN NATURAL HISTORY: WHY IT'S SO EASY TO UNDERSTAND ANIMAL BEHAVIOR

\section{J. G. Ollason}

I. Abstract ........................... 234

II. Introduction: The Design Argument in Natural Theology . . . . . . . . . . . . . . . . . . . . . . 234

III. Natural Selection As a Designer ................ 240

IV. Artificial Design: Synthesis and Analysis ........... 244

V. Apparent Design in Behavior: Optimal Foraging Theory ............................... 249

VI. Conclusion ........................ 255

VII. Acknowledgments.................... 256

VIII. References........................ 256

Chapter 10

\section{THE MISAPPROPRIATION OF TELEONOMY}

\section{Nicholas S. Thompson}

I. Abstract ......................... 259

II. Introduction ...................... 259

III. Teleonomy As an Antidote to Circular Reasoning . . . . . 260

IV. Psychology and the Concept of Objective Teleology ..... 263

A. Tolman's Purposive Behaviorism ............ 263

B. Hofstadter's Objective Teleology ............ 264

V. Biological Interpreters of Teleonomy ............ 266

A. Huxley and the Openbill's Open Bill .......... 266

B. Mayr and Determination by a Program.......... 267

C. George Williams's Natural Selection and Adaptation 268 


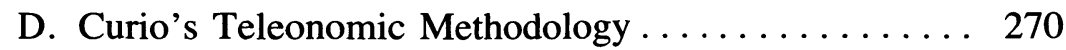

E. Pittendrigh, Reprise ................ 271

F. Conclusion: The Biological Interpreters . . . . . . 271

VI. The Appropriate Use for "Teleonomy" ........... 272

VII. Acknowledgments...................... 273

VIII. References............................. 273

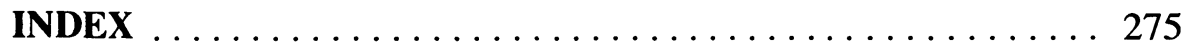

